\title{
Oxidation of 5,6-Diamino-1,3-dimethyl-2,4-dioxopyrimidine by Perrhenate. The Crystal Structure of 1,3,6,8-Tetramethylpyrimidopteridine-2,4,5,7-tetrone
}

\author{
Irvin Booysen, ${ }^{a}$ Thomas I.A. Gerber ${ }^{*, a}$ and Peter Mayer ${ }^{b}$ \\ ${ }^{a}$ Department of Chemistry, Nelson Mandela Metropolitan University, 6031 Port Elizabeth, South Africa \\ ${ }^{b}$ Department of Chemistry, Ludwig-Maximilians University, D-81377 München, Germany
}

\begin{abstract}
A oxidação de 5,6-diamino-1,3-dimetil-2,4-dioxopirimidina $\left(\mathrm{H}_{2} \mathrm{ddd}\right)$ por perrenato $\left(\mathrm{ReO}_{4}^{-}\right)$ leva à formação de 1,3-dimetilaloxano, que condensa com $\mathrm{H}_{2}$ ddd não-oxidado para produzir 1,3,6,8-tetrametilpirimidopteridino-2,4,5,7-tetrona (tppt). A estrutura do tppt consiste de um anel pirazínico central e dois anéis pirimidínicos terminais em posições cis. Os ângulos diedros entre os anéis pirazina e pirimidina são de $1,08^{\circ}$ e $1,20^{\circ}$.
\end{abstract}

The oxidation of 5,6-diamino-1,3-dimethyl-2,4-dioxopyrimidine $\left(\mathrm{H}_{2} \mathrm{ddd}\right)$ by perrhenate $\left(\mathrm{ReO}_{4}^{-}\right)$ led to the formation of 1,3-dimethylalloxan, which condenses with unoxidized $\mathrm{H}_{2}$ ddd to yield the product 1,3,6,8-tetramethylpyrimidopteridine-2,4,5,7-tetrone (tppt). The structure of tppt consists of a central pyrazine ring and two terminal pyrimidine rings in cis positions. The dihedral angles between the pyrazine and pyrimidine rings are $1.08^{\circ}$ and $1.20^{\circ}$.

Keywords: oxidation, diaminouracil, perrhenate, crystal structure

\section{Introduction}

The pyrimidine ring forms a constituent of nucleic acids, antibiotics, coenzymes and vitamins, and its coordination properties are important in understanding the role of metal ions in biological systems. ${ }^{1}$ The interest in uracil (2,4-dioxopyrimidine) derivatives arises from their potential biological activity. For example, some fluoro derivatives have shown antitumour activity ${ }^{2}$ and anti-inflammatory action. ${ }^{3}$ Uracil and its derivatives are known to bind to metal centres by using various combinations of their donor atoms, which make them versatile ligands..$^{4-6}$ For example, we have recently synthesized the complex salt $[\operatorname{Re}(\mathrm{ddd})(\mathrm{Hddd})$ $\left.\mathrm{I}\left(\mathrm{PPh}_{3}\right)_{2}\right]\left(\mathrm{ReO}_{4}\right)\left(\mathrm{H}_{2} \mathrm{ddd}=5\right.$,6-diamino-1,3-dimethyl-2,4-<smiles>Cn1c(N)c(N)c(=O)n(C)c1=O</smiles>

\footnotetext{
*e-mail: thomas.gerber@nmmu.ac.za
}

dioxopyrimidine), where ddd is coordinated monodentately through the doubly deprotonated amino nitrogen, and Hddd is coordinated bidentately via a neutral amino nitrogen and a singly deprotonated amido nitrogen.?

In this account we report on the oxidation of $\mathrm{H}_{2} \mathrm{ddd}$ to 1,3,6,8-tetramethylpyrimidopteridine-2,4,5,7-tetrone (tppt) by perrhenate $\left(\mathrm{ReO}_{4}^{-}\right)$.<smiles>Cn1c(=O)c2nc3c(=O)n(C)c(=O)n(C)c3nc2n(C)c1=O</smiles>

\section{Experimental}

Ammonium perrhenate and $\mathrm{H}_{2} \mathrm{ddd}$ were obtained commercially from Aldrich. Infrared spectra were obtained using $\mathrm{KBr}$ pellets on a Nicolet 20 DXC FTIR spectrophotometer in the $4000-200 \mathrm{~cm}^{-1}$ range, and ${ }^{1} \mathrm{H}$ NMR spectra were recorded at $300.13 \mathrm{MHz}(7.05 \mathrm{~T})$ on a Bruker AMX-300 spectrometer in dimethylsulfoxide- $\mathrm{d}_{6},\left(\mathrm{CD}_{3}\right)_{2} \mathrm{SO}$, with 
tetramethylsilane (tms) as reference. Elemental analysis was carried out by the Department of Chemistry at the University of the Western Cape in Cape Town.

\section{Synthesis of tppt}

Equimolar quantities of $\left(\mathrm{NH}_{4}\right)\left[\mathrm{ReO}_{4}\right](100 \mathrm{mg}$, $115 \mu \mathrm{mol})$ and $\mathrm{H}_{2} \mathrm{ddd}(20 \mathrm{mg}, 117 \mu \mathrm{mol})$ were added to methanol $\left(20 \mathrm{~cm}^{3}\right)$, and the mixture was heated under reflux for $3 \mathrm{~h}$ under nitrogen. After cooling to room temperature, the solution was filtered (no precipitate formed) and left to evaporate slowly at room temperature. After four days, pale yellow crystals were collected by filtration, washed with acetone and dried under vacuum. Yield 85\%, mp $255^{\circ}$ C. Anal. Calc. (\%) for $\mathrm{C}_{12} \mathrm{H}_{12} \mathrm{~N}_{6} \mathrm{O}_{4}: \mathrm{C}, 47.37$; H, 3.98; $\mathrm{N}, 27.62$. Found: C, 47.58; H, 3.89; N, 27.93. IR $v_{\max } / \mathrm{cm}^{-1}$ : $v(\mathrm{C}=\mathrm{O}) 1696,1635 ; \mathrm{v}(\mathrm{C}=\mathrm{N}) 1542 ; \delta\left(\mathrm{CH}_{3}\right) 1428 .{ }^{1} \mathrm{H}$ NMR (295 K, $\delta, \mathrm{ppm}): 2.89$ (s, 6H, C(9)H $\left.H_{3} \mathrm{C}(11) H_{3}\right) ; 2.73$ (s, $\left.6 \mathrm{H}, \mathrm{C}(10) H_{3}, \mathrm{C}(12) H_{3}\right)$.

\section{$X$-ray crystallography}

Intensity data for tppt were collected at 200(2) K on a Nonius Kappa CCD single-crystal diffractometer, using Mo- $\mathrm{K}_{\alpha}$ radiation. Unit cell and space group determinations were carried out in the usual manner. ${ }^{8}$ For the structure factors, corrections for Lorentz and polarization effects and absorption were made. The structure was solved by direct methods and refined by full matrix least-squares procedures using SHELXL-97. ${ }^{9}$ All non-hydrogen atoms were geometrically constrained.

Crystal data and structure refinement details for tppt are given in Table 1, with selected bond distances and angles shown in Table 2.

\section{Results and Discussion}

The reaction of equimolar quantities of $\left(\mathrm{NH}_{4}\right)\left[\mathrm{ReO}_{4}\right]$ with $\mathrm{H}_{2}$ ddd in methanol under reflux led to the isolation of tppt as the only product. The heating of $\mathrm{H}_{2} \mathrm{ddd}$ in the absence of perrhenate led to no reaction. The $\left[\mathrm{ReO}_{4}\right]^{-}$ anion is therefore instrumental in the formation of tppt. It has been shown previously that perrhenate reacts with 1,2-diaminobenzene $\left(\mathrm{H}_{2} \mathrm{dab}\right)$ to form the rhenium(VII) cationic complex $\left[\operatorname{Re}(\mathrm{dab})_{3}\right]^{+}$, where dab is coordinated as the diamide. ${ }^{10}$ The dab dianion can be readily oxidized by two electrons to the neutral benzoquinonediimine. ${ }^{11}$

The product tppt contains the terminal pyrimidine rings in $c i s$ positions. This phenomenon has also been observed by the reaction of $\mathrm{H}_{2} \mathrm{ddd}$ with $\mathrm{Fe}^{3+}$, which also gives tppt as product. ${ }^{12}$ However, the metal ions $\mathrm{Au}^{3+}, \mathrm{Hg}_{2}{ }^{2+}, \mathrm{Ag}^{+}$,
Table 1. Crystal data and structure refinement data for tppt

\begin{tabular}{ll}
\hline Chemical formula & $\mathrm{C}_{12} \mathrm{H}_{12} \mathrm{~N}_{6} \mathrm{O}_{4}$ \\
Formula weight & 304.26 \\
Temperature / K & $200(2)$ \\
Crystal system & Monoclinic \\
Space group & $P 2 / \mathrm{c}$ \\
Unit cell dimensions / $\left(\AA,^{\circ}\right)$ & $a=12.1393(5)$ \\
& $b=13.2545(5)$ \\
& $c=8.0862(3)$ \\
Crystal size / mm & $\beta=103.642(2)$ \\
V / ${ }^{3}$ & $0.05 \times 0.13 \times 0.13$ \\
$Z$ & $1264.37(9)$ \\
Density (calc. $) /\left(\mathrm{Mg} \mathrm{m}{ }^{-3}\right)$ & 4 \\
Absorption coefficient / $\mathrm{mm}^{-1}$ & 1.599 \\
$\theta$ range for data collection / deg & 0.124 \\
Index ranges & $3.2-27.5$ \\
Reflections measured & $-15 \leq h \leq 15 ;-16 \leq k<17 ;-10 \leq \ell \leq 10$ \\
Independent/observed reflections & 5601 \\
Data/parameters & $2881 / 1579$ \\
Goodness-of-fit on $F^{2}$ & $2881 / 203$ \\
R; $w R_{2}$ & 1.01 \\
Largest diff. peak and hole $\left(\mathrm{e} / \AA^{3}\right)$ & $0.0591 ; 0.1684$ \\
\hline
\end{tabular}

Table 2. Selected bond lengths $[\AA]$ and bond angles $\left[{ }^{\circ}\right]$ for tppt

\begin{tabular}{llll}
\hline $\mathrm{O}(1)-\mathrm{C}(1)$ & $1.208(3)$ & $\mathrm{N}(5)-\mathrm{C}(7)$ & $1.386(3)$ \\
$\mathrm{O}(2)-\mathrm{C}(2)$ & $1.219(3)$ & $\mathrm{N}(5)-\mathrm{C}(8)$ & $1.397(3)$ \\
$\mathrm{O}(3)-\mathrm{C}(7)$ & $1.223(3)$ & $\mathrm{N}(5)-\mathrm{C}(11)$ & $1.459(3)$ \\
$\mathrm{O}(4)-\mathrm{C}(8)$ & $1.205(3)$ & $\mathrm{N}(6)-\mathrm{C}(5)$ & $1.372(3)$ \\
$\mathrm{N}(1)-\mathrm{C}(1)$ & $1.397(3)$ & $\mathrm{N}(6)-\mathrm{C}(8)$ & $1.388(3)$ \\
$\mathrm{N}(1)-\mathrm{C}(2)$ & $1.384(3)$ & $\mathrm{N}(6)-\mathrm{C}(12)$ & $1.472(3)$ \\
$\mathrm{N}(1)-\mathrm{C}(9)$ & $1.472(3)$ & $\mathrm{C}(2)-\mathrm{C}(3)$ & $1.463(3)$ \\
$\mathrm{N}(2)-\mathrm{C}(1)$ & $1.387(3)$ & $\mathrm{C}(3)-\mathrm{C}(4)$ & $1.408(3)$ \\
$\mathrm{N}(2)-\mathrm{C}(4)$ & $1.365(3)$ & $\mathrm{C}(5)-\mathrm{C}(6)$ & $1.405(3)$ \\
$\mathrm{N}(2)-\mathrm{C}(10)$ & $1.480(3)$ & $\mathrm{C}(6)-\mathrm{C}(7)$ & $1.467(3)$ \\
$\mathrm{N}(3)-\mathrm{C}(4)$ & $1.334(3)$ & $\mathrm{N}(4)-\mathrm{C}(3)$ & $1.336(3)$ \\
$\mathrm{N}(3)-\mathrm{C}(5)$ & $1.334(3)$ & $\mathrm{N}(4)-\mathrm{C}(6)$ & $1.325(3)$ \\
\hline $\mathrm{C}(1)-\mathrm{N}(1)-\mathrm{C}(2)$ & $125.4(2)$ & $\mathrm{C}(5)-\mathrm{N}(6)-\mathrm{C}(12)$ & $120.0(2)$ \\
$\mathrm{C}(1)-\mathrm{N}(1)-\mathrm{C}(9)$ & $116.1(2)$ & $\mathrm{C}(8)-\mathrm{N}(6)-\mathrm{C}(12)$ & $117.7(2)$ \\
$\mathrm{C}(2)-\mathrm{N}(1)-\mathrm{C}(9)$ & $118.5(2)$ & $\mathrm{O}(1)-\mathrm{C}(1)-\mathrm{N}(1)$ & $121.1(2)$ \\
$\mathrm{C}(1)-\mathrm{N}(2)-\mathrm{C}(4)$ & $122.4(2)$ & $\mathrm{O}(1)-\mathrm{C}(1)-\mathrm{N}(2)$ & $121.7(2)$ \\
$\mathrm{C}(2)-\mathrm{N}(1)-\mathrm{C}(10)$ & $117.3(2)$ & $\mathrm{N}(1)-\mathrm{C}(1)-\mathrm{N}(2)$ & $117.1(2)$ \\
$\mathrm{C}(4)-\mathrm{N}(2)-\mathrm{C}(10)$ & $120.3(2)$ & $\mathrm{O}(2)-\mathrm{C}(2)-\mathrm{N}(1)$ & $121.7(2)$ \\
$\mathrm{C}(4)-\mathrm{N}(3)-\mathrm{C}(5)$ & $115.9(2)$ & $\mathrm{O}(2)-\mathrm{C}(2)-\mathrm{C}(3)$ & $123.8(2)$ \\
$\mathrm{C}(3)-\mathrm{N}(4)-\mathrm{C}(6)$ & $117.1(2)$ & $\mathrm{N}(1)-\mathrm{C}(2)-\mathrm{C}(3)$ & $114.4(2)$ \\
$\mathrm{C}(7)-\mathrm{N}(5)-\mathrm{C}(8)$ & $125.3(2)$ & $\mathrm{N}(4)-\mathrm{C}(3)-\mathrm{C}(2)$ & $118.0(2)$ \\
$\mathrm{C}(7)-\mathrm{N}(5)-\mathrm{C}(11)$ & $117.2(2)$ & $\mathrm{N}(4)-\mathrm{C}(3)-\mathrm{C}(4)$ & $121.2(2)$ \\
$\mathrm{C}(8)-\mathrm{N}(5)-\mathrm{C}(11)$ & $117.4(2)$ & $\mathrm{O}(4)-\mathrm{C}(8)-\mathrm{N}(5)$ & $121.5(2)$ \\
$\mathrm{C}(5)-\mathrm{N}(6)-\mathrm{C}(8)$ & $122.1(2)$ & $\mathrm{N}(2)-\mathrm{C}(4)-\mathrm{C}(3)$ & $119.7(2)$ \\
\hline
\end{tabular}

and $\mathrm{Tl}^{3+}$ also promote the oxidation of $\mathrm{H}_{2} \mathrm{ddd}$, but then the product tppt contains a trans disposition of the terminal pyrimidine rings. ${ }^{13}$

In the infrared spectrum of tppt there are two very strong absorption bands at 1696 and $1653 \mathrm{~cm}^{-1}$, which correspond to the $\mathrm{C}=\mathrm{O}$ stretching vibrations. Another strong peak at $1542 \mathrm{~cm}^{-1}$ is assigned to $\mathrm{v}(\mathrm{C}=\mathrm{N})$. The $\mathrm{CH}_{3}$ deformation vibrations are assigned to the medium-intensity band at 
$1428 \mathrm{~cm}^{-1}$, as was suggested in the literature. ${ }^{14}$ Two singlet peaks of equal intensity at 2.89 and $2.73 \mathrm{ppm}$ in the ${ }^{1} \mathrm{H}$ NMR spectrum are ascribed to the $\mathrm{C}(9) \mathrm{H}_{3} / \mathrm{C}(11) \mathrm{H}_{3}$ and $\mathrm{C}(10) \mathrm{H}_{3} / \mathrm{C}(12) \mathrm{H}_{3}$ hydrogens respectively. The compound is soluble in a wide variety of solvents, including water, chloroform, acetonitrile, dimethylsulfoxide, dimethylformamide and dichloromethane.

The X-ray crystal structure of tppt is shown in Figure 1 , together with the atom labelling scheme. The structure consists of tricyclic rings, comprising a central pyrazine ring and two terminal pyrimidine rings. The pyrimidine and pyrazine rings are essentially planar, with maximum deviations from the calculated mean plane of $0.008 \AA$ and $0.004 \AA$ respectively. In the pyrimidine rings there are some steric interactions involving the exocyclic groups, as shown by the short $\mathrm{C}(9) \cdots \mathrm{O}(1), \mathrm{O}(1) \cdots \mathrm{C}(10), \mathrm{O}(4) \cdots \mathrm{C}(11)$ and $\mathrm{O}(4) \cdots \mathrm{C}(12)$ contacts, which are $0.6 \AA$ less than the sum of the van der Waals radii. Because of these steric interactions, the exocyclic groups deviate considerably from the pyrimidine mean plane. Deviations from the plane range from -0.166(1) $\AA$ for C(9) to 0.096(1) $\AA$ for O(2). The dihedral angles between the pyrazine and pyrimidine rings are $1.08^{\circ}$ and $1.20^{\circ}$, indicating that the whole molecule is almost planar. The shortest intermolecular contact distance of $2.788(3) \AA[\mathrm{O}(2) \cdots \mathrm{C}(1)(\mathrm{x}, 1 / 2-\mathrm{y}, 1 / 2+\mathrm{z})]$ indicates that only van der Waals forces are present between molecules.

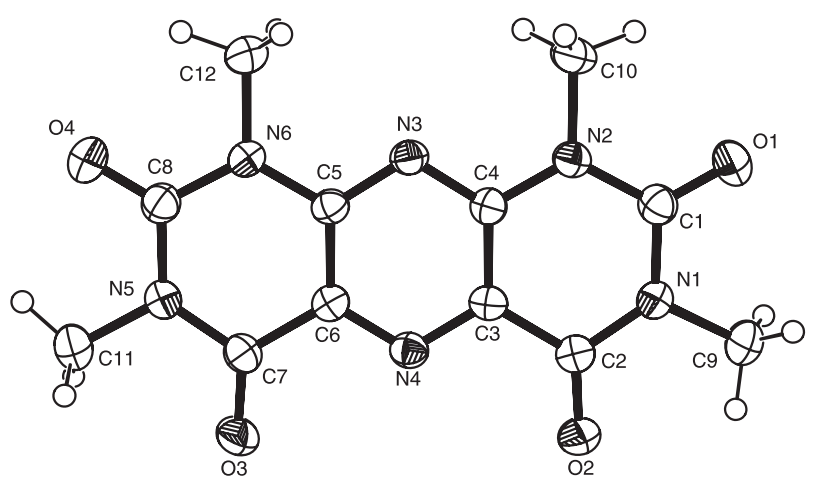

Figure 1. ORTEP view of tppt, showing the atom labelling and $40 \%$ probability displacement ellipsoids.

All C-N bonds (Table 2) in the two pyrimidine rings are single, varying in the range $1.365(3) \AA[\mathrm{N}(2)-\mathrm{C}(4)]$ to $1.397(3) \AA[\mathrm{N}(1)-\mathrm{C}(1)]$. In the pyrazine, there is electron delocalization over the $\mathrm{C}-\mathrm{N}-\mathrm{C}$ parts of the ring, with the $\mathrm{C}-\mathrm{N}$ bond lengths varying in the narrow range $1.325(3)$ to $1.336(3) \AA$.

The bond angles around the ketonic carbons, e.g. $\mathrm{O}(1)-\mathrm{C}(1)-\mathrm{N}(1)=121.1(2)^{\circ}, \mathrm{O}(2)-\mathrm{C}(2)-\mathrm{N}(1)=121.7(2)^{\circ}$, $\mathrm{O}(3)-\mathrm{C}(7)-\mathrm{N}(5)=120.9(2)^{\circ}$ and $\mathrm{O}(4)-\mathrm{C}(8)-\mathrm{N}(6)=121.3(2)^{\circ}$, are indicative of the $\mathrm{sp}^{2}$ hybridization of these carbon atoms. The angular strain around the nitrogen atoms of the two pyrimidine rings is reflected in the $\mathrm{C}-\mathrm{N}-\mathrm{C}$ bond angles, which vary from $122.1(2)^{\circ}$ to $125.4(2)^{\circ}$. In the pyrazine ring, the bond angles $\mathrm{C}(4)-\mathrm{N}(3)-\mathrm{C}(5)=115.9(2)^{\circ}$ and $\mathrm{C}(3)-\mathrm{N}(4)-\mathrm{C}(6)=117.1(2)^{\circ}$ indicate $\mathrm{sp}^{2}$ hybridization of the nitrogens.

The packing of the molecule in the unit cell is complemented by the strong inter-molecular hydrogen bonds $\mathrm{C}(10)-\mathrm{H}(10 \mathrm{C}) \cdots \mathrm{N}(4)$ and $\mathrm{C}(12)-\mathrm{H}(12 \mathrm{C}) \cdots \mathrm{O}(3)$ (see Figure 2 ), in addition to four intramolecular hydrogen bonds (see Table 3).

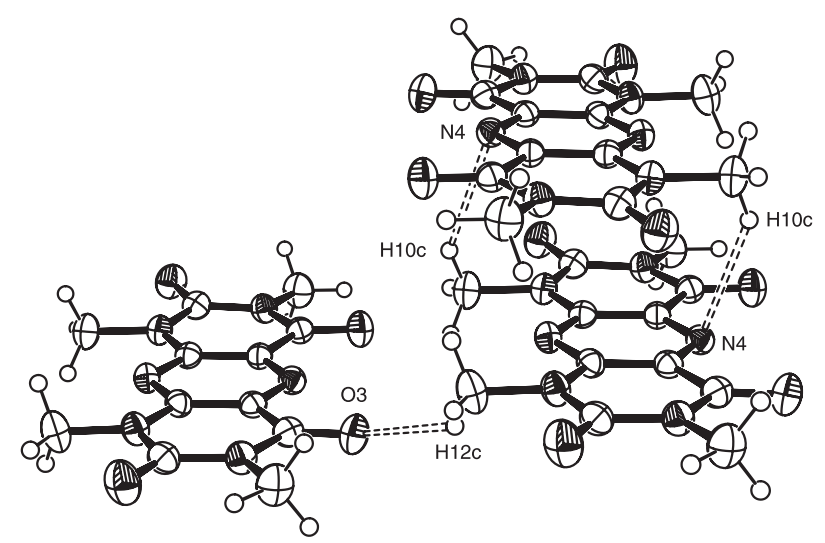

Figure 2. ORTEP drawing of the intermolecular hydrogen bonds in tppt.

Table 3. Hydrogen-bonding geometry for tppt (§, deg)

\begin{tabular}{lllllll}
\hline $\mathrm{D}$ & $\mathrm{H}$ & $\mathrm{A}$ & $\mathrm{D}-\mathrm{H}$ & $\mathrm{H} \cdots \mathrm{A}$ & $\mathrm{D} \cdots \mathrm{A}$ & $\mathrm{D}-\mathrm{H} \cdots \mathrm{A}$ \\
\hline $\mathrm{C} 9$ & $\mathrm{H} 9 \mathrm{~A}$ & $\mathrm{O} 2$ & 0.98 & 2.30 & $2.742(3)$ & 106.1 \\
$\mathrm{C} 10$ & $\mathrm{H} 10 \mathrm{~B}$ & $\mathrm{O} 1$ & 0.98 & 2.33 & $2.719(3)$ & 102.4 \\
$\mathrm{C} 10$ & $\mathrm{H} 10 \mathrm{C}$ & $\mathrm{N} 4$ & 0.98 & 2.56 & $3.386(3)$ & 141.4 \\
$\mathrm{C} 11$ & H11B & O4 & 0.98 & 2.26 & $2.713(3)$ & 107.2 \\
$\mathrm{C} 12$ & H12B & O4 & 0.98 & 2.27 & $2.714(3)$ & 106.5 \\
$\mathrm{C} 12$ & H12C & O3 & 0.98 & 2.46 & $3.252(3)$ & 138.1 \\
\hline
\end{tabular}

\section{Conclusions}

The oxidative deamination of $\mathrm{H}_{2} \mathrm{ddd}$ can be achieved by its reaction with perrhenate in methanol, to yield 1,3,6,8-tetramethylpyrimidopteridine-2,4,5,7-tetrone (tppt) as product. This compound is probably formed by condensation of the oxidation product alloxan with unoxidized $\mathrm{H}_{2}$ ddd. The crystal structure of tppt consists of a central pyrazine ring and two condensed terminal pyrimidine rings in cis positions.

\section{Acknowledgments}

I.B. is grateful to the NMMU and NRF for financial support. 


\section{Supplementary Information}

Crystallographic data have been deposited with the Cambridge Crystallographic Data Centre as supplementary material (deposition number CCDC 643784). Copies of the data can be obtained, free of charge, via www.ccdc. cam.ac.uk/conts/retrieving.html (or from the Cambridge Crystallographic Data Centre, CCDC, 12 Union Road, Cambridge CB2 1EZ, UK; fax: +44 1223 336033; or email: deposit@ccdc.cam.ac.uk).

\section{References}

1. Sorenson, J. R. J. In Metal Ions in Biological Systems; Marcel Dekker: New York, 1976, ch. 14.

2. Hibino, S.; Cancer Chemother. Rep. 1961, 13, 141.

3. Inoue, Y.; Tsobe, M.; Shiohara, T.; Hayashi, H.; Int. Arch. Allergy Immunol. 2003, 131, 143.

4. Kivekas, R.; Colacio, E.; Ruiz, J.; Lopez-Gonzalez, J. D.; Leon, P.; Inorg. Chim. Acta 1989, 159, 103.

5. Romero, M. A.; Moreno, M. N.; Ruiz, J.; Sanchez, M. P.; Nieto, F.; Inorg. Chem. 1986, 25, 1498.
6. Arriotua, M. I.; Pitarra, J. L.; Ruiz, J.; Moreno, J. M.; Colacio, E.; Inorg. Chim. Acta 1995, 231, 103.

7. Booysen, I.; Gerber, T. I. A.; Hosten, E.; Mayer, P.; J. Coord. Chem. 2007, 60, 1755.

8. Sheldrick, G. M.; Acta Crystallogr. 1990, A46, 467.

9. Sheldrick, G. M.; SHELXL-97; Program for Crystal Structure Refinement, University of Göttingen: Germany, 1997.

10. Danopoulos, A. A.; Wong, A. C. C.; Wilkinson, G.; Hursthouse, M. B.; Hussain, B.; J. Chem. Soc., Dalton Trans. 1990, 315.

11. Mederos, A.; Domínguez, S.; Hernandez-Molina, R.; Sanchiz, J.; Brito, F.; Coord. Chem. Rev. 1999, 193, 913.

12. Okamoto, Y.; Ogura, K.; Kurasawa, Y.; Kinoshita, T.; Heterocycles 1984, 22, 1231.

13. Romeresa, A.; Colacio, E.; Suarez-Varela, J.; Avila-Roson, J. C.; Hidalgo, M. A.; Romero-Garzon, J.; Acta Crystallogr. 1995, C51, 1005.

14. Al-Arab, M. M.; Hamilton, G. A.; J. Am. Chem. Soc. 1986, 108, 5972.

Received: April 18, 2007 Published on the web: January 30, 2008 